\title{
ARTHROPODS OBTAINED FROM THE AMAZONIAN TREE SPECIES “CUPIUBA" (Goupia glabra) BY REPEATED CANOPY FOGGING WITH NATURAL PYRETHRUM
}

\author{
Joachim ADIS', Ana Yoshi HARADA ${ }^{2}$, Claudio Ruy V. da FONSECA ${ }^{3}$, Wilfried \\ PAARMANN ${ }^{4}$, José Albertino RAFAEL ${ }^{3}$
}

\begin{abstract}
Two canopies of a widely distributed Amazonian tree species, Goupia glabra Aubl. (Celastraceae, height 38 and $45 \mathrm{~m}$ ) were fogged several times with $1 \%$ natural pyrethrum during the rainy and dry seasons (1991-1994) in the Adolpho Ducke Forest Reserve near Manaus/Brazil. Between 50 and 158 ind. $/ \mathrm{m}^{2}$ of arthropods were obtained per tree and fogging event. Hymenoptera, mostly Formicidae, and Diptera dominated. A total of 95 ant species occurred on a single tree. Most ants were permanently foraging in the canopy and their recolonization after fogging seems to follow stochastic pathways. Data indicated an interaction between -1) predating Formicidae and gall building Cecidomyiidae and -2) Cecidomyiidae and the parasitic Hymenoptera.
\end{abstract}

Key words: Canopy fogging, pyrethrum, arthropods, recolonization, interactions, Amazon, Neotropics.

Artrópodos Obtidos Através de Nebulização Repetitiva da Copa de uma Árvore Amazônica, "Cupiuba" (Goupia glabra), com Piretróiide Natural.

RESUMO - Duas copas de uma espécie de árvore amplamente distribuida na Amazônia, Goupia glabra Aubl. (Celastraceae, altura $38 \mathrm{e} 45 \mathrm{~m}$ ) foram renebulizadas várias vezes com piretro natural $1 \%$, durante 0 periodo chuvoso e seco (1991-94) na Reserva Florestal Adolpho Ducke próximo de Manaus/Brasil. Entre 50 e 158 ind. $/ \mathrm{m}^{2}$ de artrópodos foram obtidos por árvore e evento de nebulização. Hymenoptera, na sua maioria Formicidae, e Diptera dominaram. Um total de 95 espécies de formigas ocorreram numa única árvore. A maioria das formigas estava permanentemente forrageando na copa e a sua recolonização depois a nebulização parece seguir vias estocásticas. Os dados sugerem uma interação entre Formicidae e Cecidomyiidae (construindo galhas) e Cecidomyuidae e Hymenoptera parasitica.

Palavras-chave: Nebulização de copas, piretro, artrópodos, recolonização, interações, Amazônia, Neotrópicos.

\section{INTRODUCTION}

One possibility to explain the high within-community diversity of arthropods in the tropical canopy is that continuous stochastic local disturbances in nature are assumed to prevent the achievement of any long-term equilibrium (climax) state. These so- called stochastic non-equlilibrium models assume that the presence of a species at a vacant site is important. This may represent an advantage against all species that arrive later. Niche overlaps are assumed to be very common within species-rich communities. As a result, neither successional stages nor a climax community can

1 Max-Planck-Institute for Limnology, Tropical Ecology Working Group, Postfach 165, D-24302 Ploen, Germany.

2 Museu Paraense Emilio Goeldi, Departamento de Zoologia, Caixa Postal 399, 66.040-170, Belém, Pará, Brazil.

3 Instituto Nacional de Pesquisas da Amazônia (INPA), CPEN, Caixa Postal 478, 69011-970 Manaus/AM, Brazil.

4 Fachhochschule Hildesheim/Holzminden, Fachbereich Forstwirtschaft und Umweltmanagement, Büsgenweg 1A, D-37077 Göttingen, Germany. 
emerge. This is in contrast to the socalled deterministic equilibrium models which are based on the ecological niche. Each organism maintains a defined position in its environment and, driven by competition, the system runs through defined successional stages and ends up with a structurally predictable climax equilibrium (see Linsenmair (1990) for details).

The purpose of this study was to cause local disturbances and make sites vacant by refogging the canopy of a widely distributed Amazonian tree species. Data allow a first insight into the composition and interaction of the arthropod guild in the Neotropical canopy. In particular, into the patterns and dynamics of recolonization by species of common arthropod groups. In this contribution we focus on Hymenoptera, especially the Formicidae and Diptera.

\section{MATERIAL AND METHODS}

Our study area, the Adolpho Ducke Forest Reserve ("Reserva Ducke") is covered by $90 \mathrm{~km}^{2}$ of mostly undisturbed rainforest on terra firme latosol and is located $26 \mathrm{~km}$ north-east of Manaus ( $\left.02^{\circ} 55^{\prime} \mathrm{S}, 59^{\circ} 59^{\prime} \mathrm{W}\right)$. It belongs to the National Institute for Amazonian Research (INPA) and represents one of the most intensively studied upland forest sites in Central Amazonia (e.g. Adis et al., 1984, 1997; Hero, 1990; Höfer et al., 1994; Penny \& Arias, 1982; Prance, 1990; Willis, 1977).

Sampling was conducted on two specimens of the tree species Goupia glabra Aubl. (Celastraceae; common name "Cupiuba") which has a high local abundance and is widely distrib- uted in Amazonian upland forests (Brazil, Colombia, Venezuela and the Guianas; Loureiro \& Silva, 1968).

The first tree sampled, Cupiuba 59 (height $45 \mathrm{~m}$, crown diameter approximately $15 \mathrm{~m}$, contact to neighbouring tree canopies sporadical, no lianes nor epiphytes) was fogged with a Swingfog SN 50 two times per day in August 1991 (dry season; Ribeiro \& Adis, 1984) on two consecutive days. The fogging machine was hoisted into the lower canopy on a rope and pulley system early in the morning. Release of the insecticide (Fig. 1) was controlled from the ground by radio-control. Subsequently, the fog was directed to all parts of the crown by rotating the fogger round $180^{\circ}$ with the rope from which it was suspended (Erwin, 1983). As knockdown agent, a $1 \%$ solution of natural pyrethrum (without synergist) diluted in diesel oil was used for the first three fogging events and synthetic pyrethrum Baythroid $0.15 \%$ for the fourth fogging. The knockdown effect of the killing agent Baythroid was stated by the manufacturer (Bayer, Leverkusen/Germany, personal communication) to be 10 times more effective than that of the non-killing natural pyrethrum. After each fogging, arthropods were intercepted in 18 funnel-shaped collecting trays placed directly under the canopy. They were made of a fine, smooth nylon fabric on a metal frame (Stork \& Brendell, 1990). They hung about $1 \mathrm{~m}$ above the ground and up to $5 \mathrm{~m}$ from the tree trunk on a web of ropes tied about head-height on available tree trunks (Fig. 2). At the end of each drop period ( 1 or $2 \mathrm{hrs}$ ), specimens were washed down the funnel 


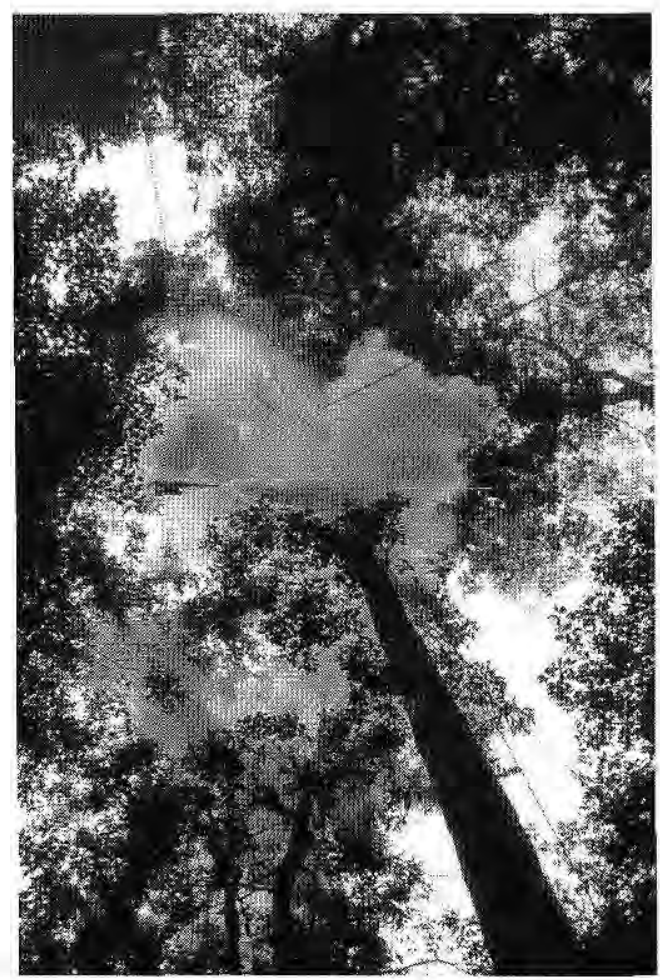

Figure 1. A cloud or natural pyretnrum tog is produced oy a togging machine at dawn and rises through the canopy of a $45 \mathrm{~m}$ high Goupia glabra (Cupiuba 59; photo J. Adis).

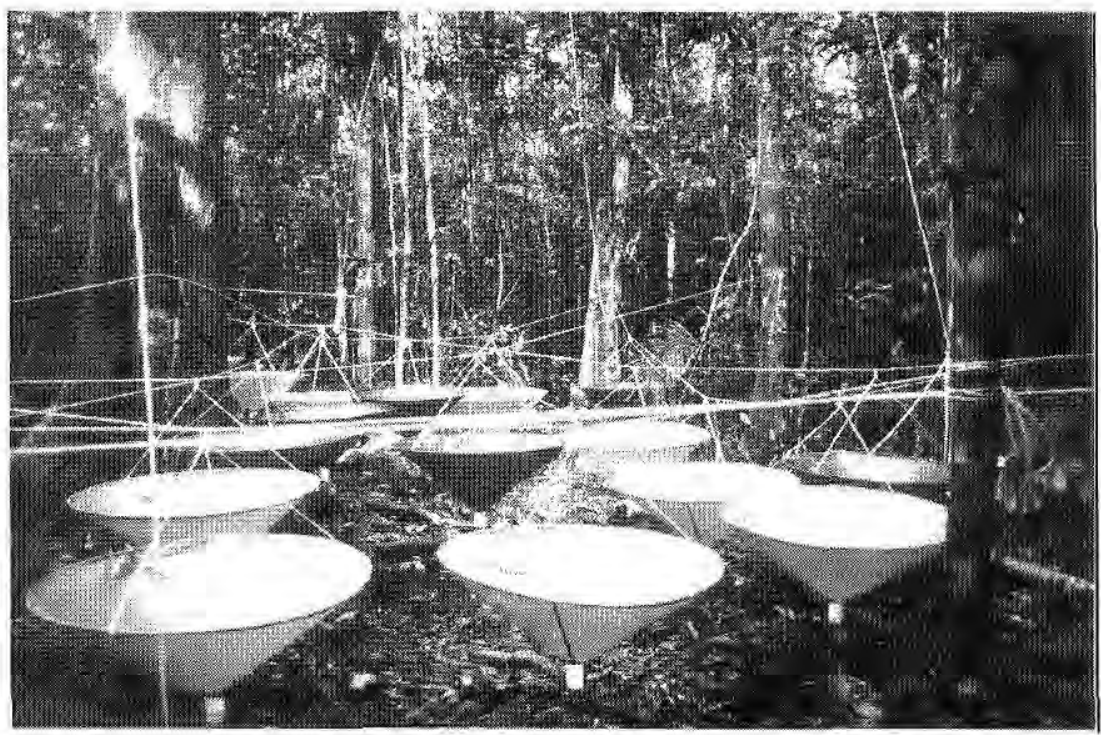

Figure 2. Funnel-shaped collecting trays are suspended from ropes under the canopy of Goupia glabra (Cupiuba 59; photo J. Adis) 
walls with a garden sprayer filled with $70 \%$ ethanol into plastic bottles attached to the funnel outlet (Erwin, 1989). Cupiuba 59 was refogged after 6 or 24 months with $1 \%$ natural pyrethrum (without synergist) during the rainy season (February, 1992) and the dry season (August, 1992 and July, 1994).

A second tree specimen, Cupiuba 64 (height $38 \mathrm{~m}$, crown diameter about $14 \mathrm{~m}$, contact to neighbouring trees sporadical, no lianes nor epiphytes) was fogged for the first time with $1 \%$ natural pyrethrum (without synergist) in February, 1992 (rainy season) and refogged 6 and 24 month later during the dry season (August, 1992 and July, 1994). This tree was about $1 \mathrm{~km}$ distant from Cupiuba 59. Further details of study site and fogging methodology are given in Adis et al., (1997). Relative abundances (ind $/ \mathrm{m}^{2}$ ) represent the calculated mean of arthropods obtained in the 18 collecting trays which were installed below the canopy of each tree per fogging event.

\section{RESULTS AND DISCUSSION}

Between 898 and 2850 arthropods (50 - 158 ind. $/ \mathrm{m}^{2}$ ) were collected per fogging event đuring the dry and rainy seasons in the 18 trays installed below the canopies of Cupiuba 59 and 64 (Figs. 3, 4). Hymenoptera $(51 \%)$, mostly Formicidae $(45 \%)$ and Diptera $(58 \%)$ dominated. The higher proportion of Coleoptera during the rainy season (February, 1992) on Cupiuba 59 was due to Chrysomelidae (12 spp.). A total of 95 ant species were obtained from the canopy of one single tree (Tab. 2: Cupiuba 59; cf. Harada \& Adis, 1997). This is close to the total number of ant species recorded from Germany ( $n=105$; Seifert, 1993).

The composition of the arthropod fauna in the canopy may differ between tree species. For example, in contrast to the results obtained from Cupiuba, the sample density of Hymenoptera and Coleoptera collected from the canopies of Eschweilera $\mathrm{cf}$. odora (Lecythidaceae; height $30-35 \mathrm{~m}$ ) and Dipteryx alata (Leguminosae; height $30 \mathrm{~m}$ ) in the same forest reserve was higher than that of Diptera. Half the species of ants obtained from $D$. alata did not occur on $E$. cf. odora (Adis et al., 1984).

In our study, each fogging event represented a local disturbance. The occurrence of ants in the Cupiuba canopy after fogging seems to be incidental and to follow stochastic pathways. Most of the highly mobile ants are permanently foraging in the canopy. This is indicated by the high amount of singletons and dubletons per species (Tab. 3; cf. Harada \& Adis, 1997). At least $69 \%$ of them represented arboricolous species. There was evidence that ants immigrated within 24 hours after canopy fogging from neighbouring trees with overlapping canopies, from the lower trunk region, and from the forest floor (Harada \& Adis, 1997). A species turnover of $50 \%$ between fogging events (Tab. 3) mainly concerned the rare species. Results are different from fogging studies in the canopy of understorey trees ( $3 \mathrm{sp}$; height $28 \mathrm{~m}$ ) in a lowland forest in Sabah, Malaysia (Floren \& Linsenmair, 1997a,b). Here, only few 


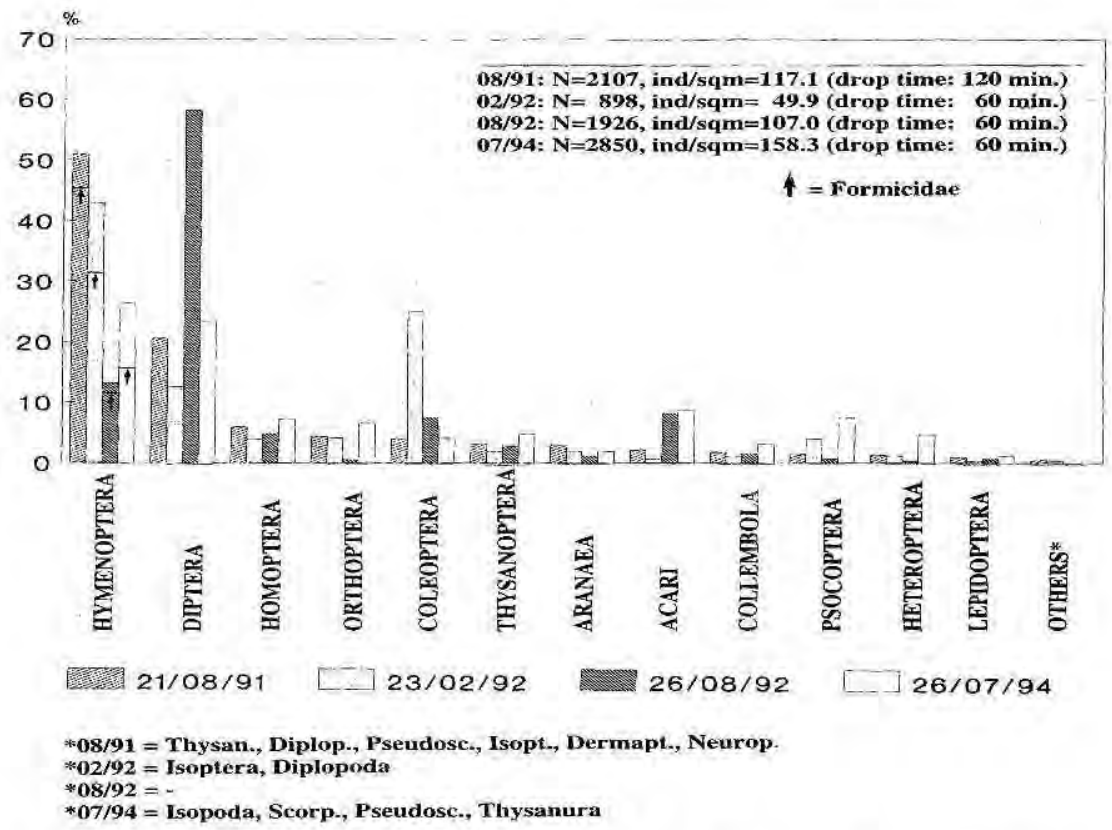

Figure 3. Dominance, total number and abundance of arthropods obtained by fogging the canopy of Cupiuba 59 (Goupia glabra) with 1\% natural pyrethrum between 1991 and 1994 at Reserva Ducke near Manaus.

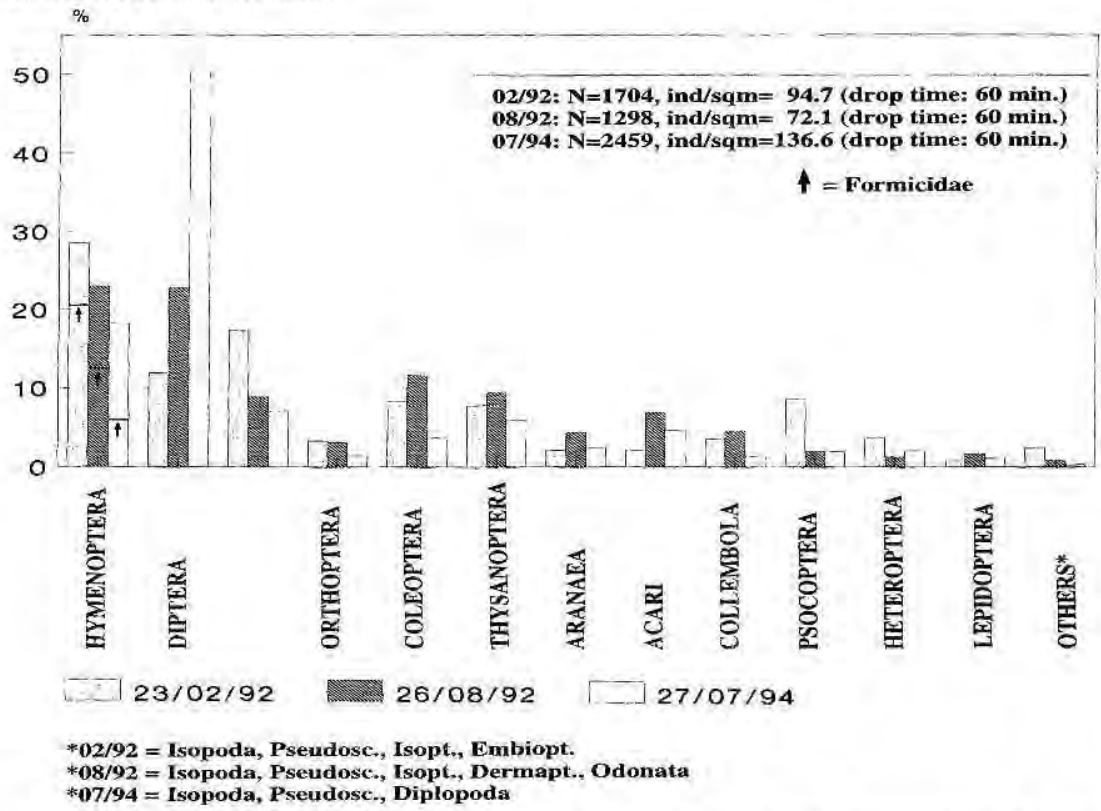

Figure 4. Dominance, total number and abundance of arthropods obtained by fogging the canopy of Cupiuba 64 (Goupia glabra) with 1\% natural pyrethrum between 1992 and 1994 at Reserva Ducke near Manaus. 
Table 1. Numbers and percentage of Diptera families obtained by fogging the canopy of two Cupiuba trees (Goupia glabra) with 1\% natural pyrethrum between 1992 and 1994 at Reserva Ducke near Manaus.

\begin{tabular}{|c|c|c|c|c|c|c|c|c|c|c|c|c|}
\hline & \multicolumn{5}{|c|}{ Cupiuba 59} & \multicolumn{5}{|c|}{ Cupiuba 64} & \multicolumn{2}{|c|}{ Cupiuba $59 \& 64$} \\
\hline DIPTERA. & $02 / 92$ & 08192 & $07 / 94$ & Total & $\%$ & $02 / 92$ & $08 / 92$ & 07194 & Total & $\%$ & sum & $\%$ \\
\hline Nematocera & 57 & 1159 & 812 & 2028 & 92.1 & 100 & 195 & 1505 & 1800 & 91.6 & 3828 & 91.9 \\
\hline Cecidomyiidae & 27 & 850 & 385 & 1262 & 57.3 & 50 & 119 & 766 & 935 & 47.6 & 2197 & 52.7 \\
\hline Ceratopogonidae & 2 & 32 & 133 & 167 & 7.6 & 1 & 11 & 428 & 440 & 22.4 & 607 & 14.6 \\
\hline Chironomidae & 8 & 89 & 213 & 310 & 14.1 & 21 & 14 & 224 & 259 & 13.2 & 569 & 13.7 \\
\hline Sciaridae & 14 & 167 & 45 & 226 & 10.3 & 22 & 35 & 52 & 109 & 5.5 & 335 & 8.0 \\
\hline Tipulidae & - & 5 & 7 & 12 & 0.5 & - & 1 & 18 & 19 & 1.0 & 31 & 0.7 \\
\hline Culicidae & 1 & 3 & 5 & 9 & 0.4 & - & 1 & 4 & 5 & 0.2 & 14 & 0.3 \\
\hline Mycetophilidae & 1 & 3 & 11 & 15 & 0.7 & 1 & 13 & 6 & 20 & 1.0 & 35 & 0.8 \\
\hline Psychodidae & 4 & 10 & 13 & 27 & 1.2 & 5 & 1 & 7 & 13 & 0.7 & 40 & 1,0 \\
\hline Brachycera & 41 & 39 & 94 & 174 & 7.9 & 37 & 35 & 93 & 165 & 8.4 & 339 & 8.1 \\
\hline Dolichopodidae & 1 & 8 & 52 & 61 & 2.8 & 6 & 10 & 64 & 80 & 4.1 & 141 & 3.4 \\
\hline Phoridae & 17 & 8 & 13 & 38 & 1.7 & 6 & 14 & 7 & 27 & 1.4 & 65 & 1.6 \\
\hline Empididae & 1 & 8 & 1 & 10 & 0.5 & - & - & 1 & 1 & $<0.1$ & 11 & 0.3 \\
\hline Milichidae & 2 & 1 & 13 & 16 & 0.7 & - & 5 & 13 & 18 & 0.9 & 34 & 0.8 \\
\hline Drosophilidae & 14 & 4 & 2 & 20 & 0.9 & 4 & 1 & 5 & 10 & 0.5 & 30 & 0.7 \\
\hline Others & 6 & 10 & 13 & 29 & 1.3 & 21 & 5 & 3 & 29 & 1.5 & 58 & 1.4 \\
\hline SUM & 98 & 1198 & 906 & 2202 & 100.0 & 137 & 230 & 1598 & 1965 & 100.0 & 4167 & 100.0 \\
\hline$\%$ & 4.5 & 54.4 & 41.1 & 100.0 & - & 7.0 & 11.7 & 81.3 & 100.0 & - & - & - \\
\hline
\end{tabular}

additional species were recorded after refogging of trees and most ant species represented trunk inhabitants that had survived the fogging events.

The species composition of ants in each of the two Cupiuba canopies sampled were distinct. Fifty-seven $(46.0 \%)$ out of the total 124 ant species were obtained solely from Cupiuba 59 and 28 species (22.6\%) only from Cupiuba 64 (data calculated from Table 17.1 in Harada \& Adis (1997) and from Table 2 in this study). Adis et al. (1984) found $43 \%$ of the total ant species ( $\mathrm{n}=21,2580$ ind.) to occur only in the canopy of one tree of $E$. cf. odora and $24 \%$ solely in a second tree canopy of this species.

Only 2-6 nests were obtained per Cupiuba tree and fogging event, and (re)colonization (cf. Tab. 3), i.e. nidification of ant species, was low. In the case of Cephalotes atratus (Tab. 2), the reason might be the presence of Membracidae (Homoptera) like Richteria peruviana (Funkhouser) which live in the canopy of various Neotropical tree species and produce honeydew the ants feed on (Strümpel, 1985). A low number of ant nests was also found in the canopy of Cupiuba trees at the Rio Orinoco in Venezuela, based on visual observations from a crane (Schmücke \& Morawetz, personal communication).

At fogging intervals of six months, the number of ants collected decreased continuously (from $45 \%$ to $5 \%$ of the total catch), whereas the amount of Diptera (in particular gall building Cecidomyiidae; cf. Table 1) and other (mainly parasitic) $\mathrm{Hy}$ menoptera increased (from 12\% to $58 \%$ and from $6 \%$ to $12 \%$ (except in August, 1992), respectively). This tendency was also observed after a fogging interval of two years (1992-94) if only few ants had returned to forage in the tree canopy. This was true in Cupiuba 64 (Fig. 5: bottom), where both number of specimens and species were similar in August, 1992 compared to 
Table 2. Ant species obtained from two Cupiuba trees (Goupia glabra) at Reserva Ducke near Manaus by refogging the canopy after two years with $1 \%$ natural pyrethrum during the dry season (July, 1992). Data on ant species collected during previous fogging events are given in Harada \& Adis (1997).

\begin{tabular}{|c|c|c|c|c|c|c|c|}
\hline FORMICIDAE & Cupiuba 59 & Cupiuba 64 & Total & $\mathrm{x}$ & a & $t$ & $?$ \\
\hline \multicolumn{8}{|l|}{ Subf. Dolichoderinae } \\
\hline - Azteca nr. delpini & - & 9 & 9 & 2,6 & $x ?$ & & \\
\hline Dolichoderus diversus & 1 & - & 1 & 5,1 & $x$ & & \\
\hline Dolichoderus lutosus & 4 & - & 4 & 3,4 & $\mathbf{x}$ & & \\
\hline${ }^{\circ}$ Dolichoderus rugosus & 1 & - & 1 & 10,6 & & $\mathrm{x}$ & \\
\hline - Tapinoma amazonicum & 1 & 2 & 3 & 1,5 & $x ?$ & & \\
\hline - Tapinoma ramulorum & - & 3 & 3 & 1,8 & $\mathrm{x} ?$ & & \\
\hline \multicolumn{8}{|l|}{ Subf. Formicinae } \\
\hline Camponotus abdominalis A & - & 1 & 1 & 6,5 & & & $\mathrm{x}$ \\
\hline Camponotus alboannulatus A & 1 & - & 1 & 4,8 & & & $x$ \\
\hline Camponotus alboannulatus B & - & 1 & 1 & 4,5 & & & $x$ \\
\hline - Camponotus brasiliensis & 1 & 32 & 33 & 3,2 & $x$ & $x$ & \\
\hline - Camponotus coptobregma & 2 & - & 2 & 5,7 & & & $\mathrm{x}$ \\
\hline Camponotus crassus & 28 & - & 28 & 3,7 & $x ?$ & & \\
\hline - Camponotus eurynota & 6 & - & 6 & 3,3 & & & $x$ \\
\hline ' Camponotus femuratus & 1 & - & 1 & 4,7 & $x$ & & \\
\hline Camponotus nr. abdominalis & - & 1 & 1 & 5 & & & $x$ \\
\hline Camponotus /uederwaldti & 2 & - & 2 & 3,1 & & & $\mathrm{x}$ \\
\hline Camponotus nr. bidens & 7 & 23 & 30 & 3 & & & $\mathrm{x}$ \\
\hline - Camponotus pittieri & 44 & 12 & 56 & 3 & & & $x$ \\
\hline Camponotus rapax & + & 1 & 1 & 7,9 & $x ?$ & & \\
\hline Camponotus sp. 34 & 7 & - & 7 & 3,7 & & & $x$ \\
\hline - Camponotus sp.49 & 1 & - & 1 & 7 & & & $x$ \\
\hline Dendromyrmex fabricii & 1 & - & 1 & 5,7 & & & $\mathrm{x}$ \\
\hline \multicolumn{8}{|l|}{ Subf. Myrmicinae } \\
\hline Cephalotes atratus & 129 & 15 & 144 & 10,1 & $x$ & & \\
\hline Procryptocerus goeldii & 6 & 7 & 13 & 4 & $x$ & & \\
\hline Procryptocerus marginatus & 15 & 5 & 20 & 5,8 & $\mathrm{x}$ & & \\
\hline Zacryptocerus duckei & 1 & - & 1 & 3 & $\mathrm{x}$ & & \\
\hline Zacryptocerus sp. 22 & 2 & - & 2 & 2,5 & $x ?$ & & \\
\hline Crematogaster sp. 1 & - & 1 & 1 & 2 & $x ?$ & & \\
\hline Crematogaster sp. 2 & 11 & 1 & 12 & 2,2 & $x ?$ & & \\
\hline Crematogaster sp. 3 & 14 & 1 & 15 & 2,2 & $x ?$ & & \\
\hline Crematogaster limata & 3 & - & 3 & 2,7 & $x ?$ & & \\
\hline Crematogaster sp. 7 & 8 & - & 8 & 2,6 & $x ?$ & & \\
\hline Crematogaster sp. 8 & - & 6 & 6 & 2,5 & $x ?$ & & \\
\hline Crematogaster sp. 9 & 1 & - & 1 & 2 & $x ?$ & & \\
\hline Crematogaster sp. 10 & 88 & 9 & 97 & 1,9 & $x ?$ & & \\
\hline Leptothorax (Nesomyrmex) sp. 2 & 19 & 1 & 20 & 1,6 & $x ?$ & & \\
\hline - Leptothorax (Nesomyrmex) sp. 9 & - & $1 *$ & 1 & 3 & $x ?$ & & \\
\hline - Megalomyrmex balzani & - & 2 & 2 & 7,6 & $\mathrm{x}$ & & \\
\hline - Pheidole sp. 14 & 11 & - & 11 & 1,4 & $x ?$ & & \\
\hline - Pheidole sp. 15 & - & 5 & 5 & 1,4 & $x ?$ & & \\
\hline Pheiddo sp 18 & - & 13 & 13 & 1,1 & $x ?$ & & \\
\hline Pheidole sp. 55 & 1 & - & 1 & 1,6 & $x ?$ & & \\
\hline - Pheidole sp. 68 & - & $1^{*}$ & 1 & 3,2 & $x ?$ & & \\
\hline Solenopsis (Diplorhoptrum) sp. 8 & - & 1 & 1 & 1,1 & $x ?$ & & \\
\hline${ }^{\circ}$ Cyphomyrmex dentatus & - & 2 & 2 & 1,9 & $x ?$ & & \\
\hline \multicolumn{8}{|l|}{ Subf. Pseudomyrmecinae } \\
\hline - Pseudomyrmex elongatus & 1 & - & 1 & 3,1 & $\mathrm{x}$ ? & & \\
\hline - Pseudomyrmex oculatus & 1 & - & 1 & 4,1 & $x ?$ & & \\
\hline Pseudomyrmex pupa & 3 & - & 3 & 6,5 & $x$ & & \\
\hline \multicolumn{8}{|l|}{ Subf. Ponerinae } \\
\hline - Discothyrea sexarticulata & - & $1^{*}$ & 1 & 1,3 & $x ?$ & & \\
\hline - Hypoponera sp. 33 & $=$ & $1^{*}$ & 1 & 2,8 & $x ?$ & & \\
\hline Total no. of ants & 422 & 158 & 580 & & & & \\
\hline Total no. of species & 33 & 28 & 50 & & 37 & 2 & 12 \\
\hline Total no. of genera & 11 & 13 & 17 & & 16 & 2 & 2 \\
\hline
\end{tabular}

${ }^{\circ}=$ collected for the first time; $\mathrm{x}=$ mean body length $(\mathrm{mm}) ; \mathrm{a}=$ arboricolous;

$\mathrm{t}=$ terricolous; ? = habitat uncertain; ${ }^{*}=$ queen; $-=$ no records. 
Table 3. Comparison of the ant fauna obtained from two Cupiuba trees (Goupta glabra) at Reserva Ducke near Manaus by fogging the canopy between 1991 and 1994. Data based on ant specics given in Table 17,1 of Harada \& Adis (1997) and in Table 2 of this study. (The insecticide applied was $1 \%$ natural pyrethrum, except at the fourth fogging event in August, 1991 during which synthetic pyrethrum Baythroid $0.15 \%$ was used; \langle\rangle$=$ data of the first fog event; see text for details).

\begin{tabular}{|c|c|c|c|c|c|c|c|c|c|c|}
\hline \multirow{3}{*}{$\begin{array}{l}\text { FORMICIDAE } \\
\text { no. of fogging events }\end{array}$} & \multicolumn{6}{|c|}{ Cupiuba 59} & \multicolumn{4}{|c|}{ Cupiuba 64} \\
\hline & \multicolumn{2}{|c|}{$8 / 91$} & \multirow{2}{*}{$\frac{2 / 92}{1 \times}$} & \multirow{2}{*}{$\frac{8 / 92}{1 x}$} & \multirow{2}{*}{$\begin{array}{l}7 / 94 \\
1 \times\end{array}$} & \multirow{2}{*}{$\begin{array}{l}\text { Total } \\
7 x\end{array}$} & \multirow{2}{*}{$\frac{2192}{1 x}$} & \multirow{2}{*}{$\frac{8 / 92}{1 \mathrm{x}}$} & \multirow{2}{*}{$\frac{7 / 94}{1 x}$} & \multirow{2}{*}{$\begin{array}{c}\text { Total } \\
3 x\end{array}$} \\
\hline & $4 x$ & $\langle 1 x\rangle$ & & & & & & & & \\
\hline no. of ants & 1718 & $\langle 905\rangle$ & 334 & 85 & 422 & 2559 & 328 & 148 & 158 & 634 \\
\hline no. of species & 67 & $\langle 43\rangle$ & 25 & 20 & 33 & 95 & 33 & 28 & 28 & 59 \\
\hline ratio ants/species & 25.6 & $\langle 21.0\rangle$ & 13.4 & 4.3 & 12.8 & 26.8 & 9.9 & 5.3 & 5.6 & 10.7 \\
\hline no. of genera & 16 & $\langle 15\rangle$ & 14 & 11 & 11 & 19 & 12 & 12 & 13 & 19 \\
\hline singletons per species & $\begin{array}{c}27 \\
(40.3 \%) \\
\end{array}$ & $\begin{array}{c}\langle 11\rangle \\
\langle(25.6 \%)\rangle\end{array}$ & $\begin{array}{c}13 \\
(52.0 \%)\end{array}$ & $\begin{array}{c}11 \\
(55.0 \%)\end{array}$ & $\begin{array}{c}13 \\
(39.4 \%)\end{array}$ & $\begin{array}{c}40 \\
(49.4 \%) \\
\end{array}$ & $\begin{array}{c}13 \\
(39.4 \%) \\
\end{array}$ & $\begin{array}{c}10 \\
(35.7 \%)\end{array}$ & $\begin{array}{c}13 \\
(46.4 \%)\end{array}$ & $\begin{array}{c}17 \\
(27.9 \%) \\
\end{array}$ \\
\hline dubletons per species & $\begin{array}{c}8 \\
(11.9 \%)\end{array}$ & $\begin{array}{c}\langle 5\rangle \\
\langle(11.6 \%)>\end{array}$ & $\begin{array}{c}3 \\
(12.0 \%) \\
\end{array}$ & $\begin{array}{c}6 \\
(30.0 \%) \\
\end{array}$ & $\begin{array}{c}3 \\
(8.8 \%)\end{array}$ & $\begin{array}{c}11 \\
(13.6 \%) \\
\end{array}$ & $\begin{array}{c}4 \\
(12.1 \%)\end{array}$ & $\begin{array}{c}6 \\
(21.4 \%) \\
\end{array}$ & $\begin{array}{c}3 \\
(10.7 \%)\end{array}$ & $\begin{array}{c}10 \\
(16.4 \%)\end{array}$ \\
\hline $\begin{array}{l}\text { abundant species } \\
(>25 \text { ind.) }\end{array}$ & $\begin{array}{c}6 \\
(9.0 \%)\end{array}$ & $\begin{array}{c}\langle 6\rangle \\
\langle(14,9 \%)\rangle\end{array}$ & $\begin{array}{c}2 \\
(8.0 \%)\end{array}$ & $\begin{array}{c}1 \\
(5.0 \%) \\
\end{array}$ & $\begin{array}{c}4 \\
(11.8 \%)\end{array}$ & $\begin{array}{c}14 \\
(14.4 \%)\end{array}$ & $\begin{array}{c}3 \\
(9.1 \%)\end{array}$ & $\begin{array}{c}0 \\
(0.0 \%)\end{array}$ & $\begin{array}{c}18 \\
(64.3 \%)\end{array}$ & $\begin{array}{c}4 \\
(6.6 \%)\end{array}$ \\
\hline species tumover & - & . & $\begin{array}{c}9 \\
(36.0 \%) \\
\end{array}$ & $\begin{array}{c}6 \\
(30.0 \%)\end{array}$ & $\begin{array}{c}14 \\
(42.4 \%)\end{array}$ & . & $\cdot$ & $\begin{array}{c}14 \\
(50.0 \%) \\
\end{array}$ & $\begin{array}{c}1 \\
(3.6 \%)\end{array}$ & . \\
\hline $\begin{array}{l}\text { recolonization of } \\
\text { species }\end{array}$ & . & $\cdot$ & 0 & 1 & 3 & $\cdot$ & $\cdot$ & 0 & $\begin{array}{c}2 \\
(7.1 \%)\end{array}$ & . \\
\hline $\begin{array}{l}\text { colonization of } \\
\text { additional species }\end{array}$ & . & . & 0 & 0 & 2 & $\cdot$ & $=$ & 0 & $4-6$ & 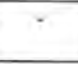 \\
\hline
\end{tabular}

July, 1994 (Tab. 3). The number of Cecidomyiidae, however, increased (from 119 to 766 specimens; Tab. 1). The opposite was observed in Cupiuba 59: the number of ant specimens and species had increased (from 88 to 422 and from 20 to 33, respectively; Tab. 3) but the amount of Cecidomyiidae had decreased (from 850 to 385 specimens (Tab. 1), results at species level not yet available; cf. Fig. 5: top). Data indicate a biotic interaction between - 1) predating ants (probably Crematogaster spp.) and the gall building Cecidomyiidae and - 2) between Cecidomyiidae and the parasitic Hymenoptera. This was not known from previous studies in the tropical canopy. To our knowledge (Adis et al., 1998), there are no field data showing the specific predation of Diptera (eggs, larvae, pupae, "galls") by ants.

Some ecological investigations, however, have led to the assumption that -1 ) the population density of leaf- mining larvae of Diptera and Lepidoptera is being non-selectively controlled by ants; -2 ) the exclusion of ants can have a direct effect on the attack of parasitoids if ants interfere with searching by the adult parasitoid. Thus herbivores tended by ants have been shown to suffer less parasitoid attack than untended herbivores (see review in Memmott et al., 1993).

Stork $(1988,1991)$ obtained a low number of ant species $(n=10-32$; $3.1 \%$ of the total arthropod species) from each of ten Bornean canopies in a lowland floodplain forest, but a high number of species of other $\mathrm{Hy}$ menoptera $(n=37-267 ; 23 \%$ of the total arthropod species), predominantly parasitic Chalcidoidea (739 species) The families of Nematocera known to parasitise the galls of Cecidomyiidae in Central Amazonian tree canopies (Eulophidae, Eurytomidae, Pteromalidaé, Torymidae; Adis et al., 1998) represented $40 \%(n=298)$ of the Chalcidoidea species 
Figure 5. Percentage of Diptera, Cecidomyiidae, Formicidae and other (mainly parasitic) Hymenoptera of the total number of arthropods (N) obtained by canopy fogging between 1991 and 1994 from two Cupiuba trees (Goupia glabra) at Reserva Ducke near Manaus (refogging intervals 6 or 24 months).

\section{Cupiuba 59}

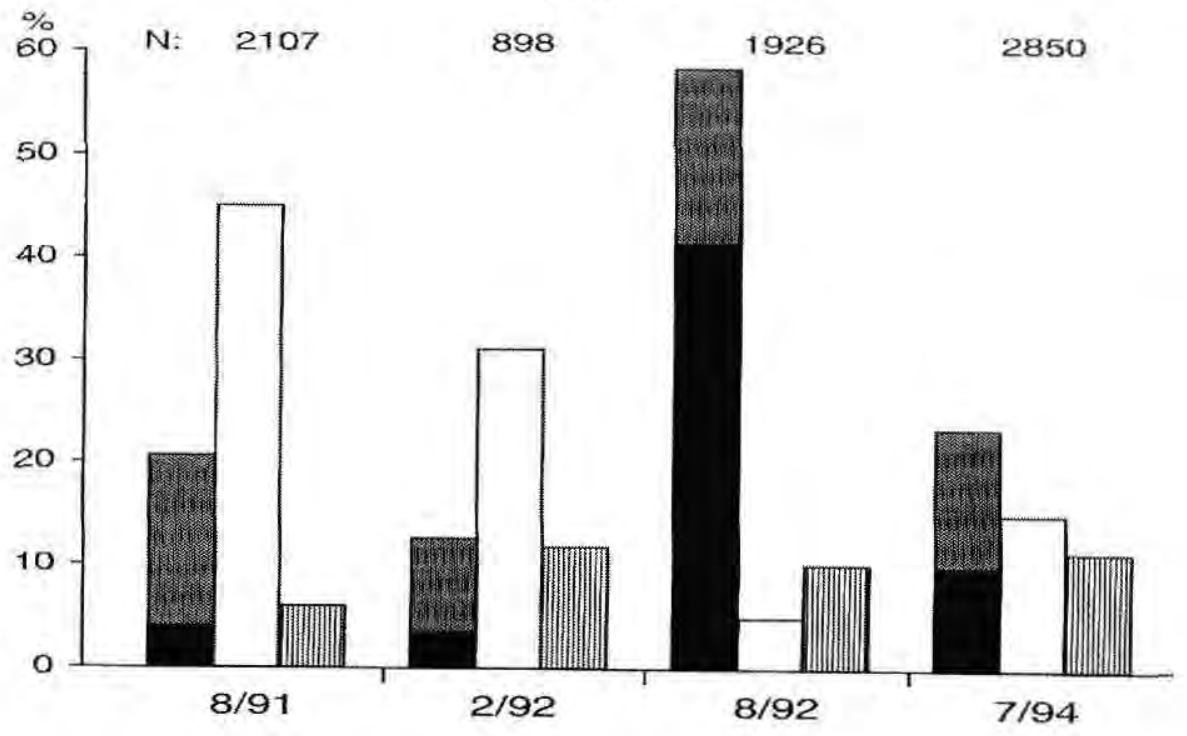

Cupiuba 64

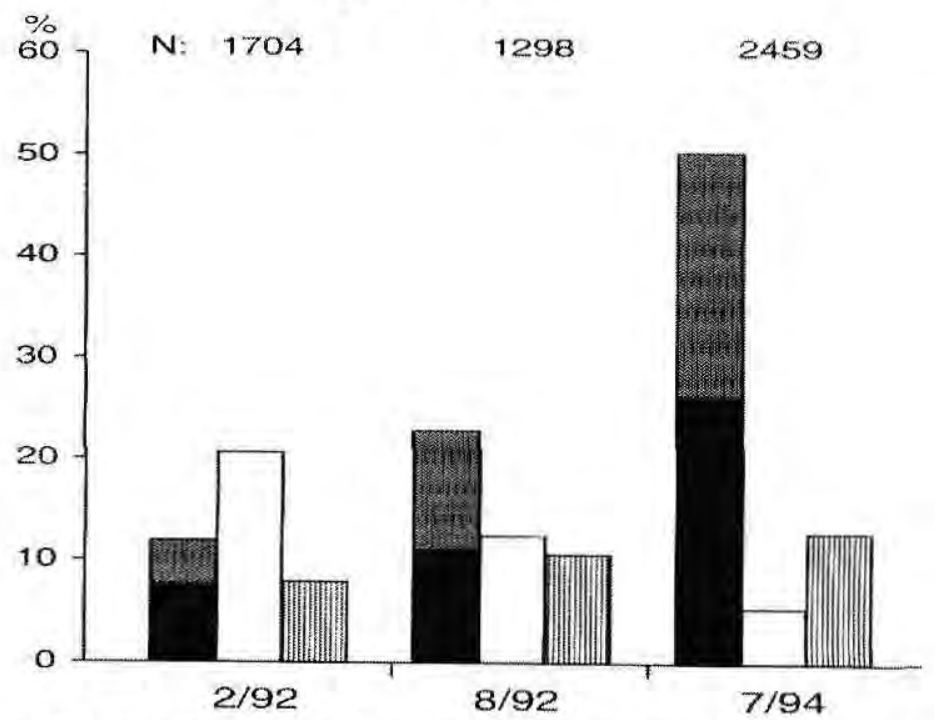

- Cecidomyildae other Diptera $\square$ Formicidae m other Hymenoptera 
and $46 \%(n=667)$ of all specimens obtained on Borneo. The Diptera on Borneo amounted to $22 \%$ of the arthropod species and specimens collected. The Cecidomyiidae, Ceratopognidae, Chironomidae and Sciaridae represented $91 \%(n=3362)$ of the specimens and $69 \%(n=119)$ of the species of all the Nematocera obtained. At Manaus (Tab. 1), specimens of these groups amounted to $89 \%$ of the total Nematocera. The Cecidomyiidae represented $47-62 \%$ of the Nematocera specimens collected and at least 13 species (preliminary classification on morphospecies level). On Borneo, 26 species of Cecidomyiidae represented $15 \%$ of the total Nematocera specimens.

The data from tree canopies on Borneo suggest that a low number of ant species might result in a reduced predation of Cecidomyiidae galls by ants, which favours an interaction primarily between the parasitic Hymenoptera and the Cecidomyiidae. Field experiments might elucidate the general interactions between Formicidae, Cecidomyiidae and parasitic Hymenoptera in both Neotropical and Southeast Asian canopies of tropical lowland forests. At Manaus and at the Rio Orinoco, twigs of trees with Cecidomyiidae galls could be protected from ant attacks, e.g. by mesh-bags. On Borneo, carton nests of non-competitive ant species could be added to the canopy (Maschwitz, personal communication) and the response of gall building Cecidomyiidae monitored. In both cases, however, results have to be compared on species level.

\section{ACKNOWLEDGEMENTS}

This study is part of a 6-year project on "Mechanisms that maintain tropical di- versity', funded by the German Research Foundation, the German Agency of Technical Cooperation (GTZ: project 85.2522.2-06100) and the Brazilian Research Foundation (CNPq: project CNPq' MPG 91.0304/90-4) since 1991. Sincere thanks are expressed to PD Dr. W.J. Junk and Dr. Maria Teresa Fernandez Piedade for logistical support in Manaus via the 'Projeto INPA/Max-Planck'. We heartily thank all scientists of the diversity project and of INPA, the technical staff of INPA as well as the participants of the postgraduate course 'Entomological Field Ecology' of INPA/Univ. Amazonas (February 1992) who joined the canopy fogging studies. Dr. Helen Read, Burnham Beeches, Slough/ United Kindom, Dr. Terry L. Erwin, Smithsonian Institution, Washington D.C./USA, and Prof. Dr. Stefan Vidal, University of Giessen/Germany gave valuable comments which helped to improve the manuscript.

\section{Literature cited}

Adis, J.; Lubin, Y.D.; Montgomery, G.G. 1984. Arthropods from the canopy of inundated and terra firme forests near Manaus, Brazil, with critical considerations on the pyrethrum-fogging technique. Studies on Neotropical Fauna and Environment, 19(4): 223-236.

Adis, J; Paarmann, W; Fonseca, C.R.V. da; Rafael, J.A. 1997. Knockdown efficiency of natural pyrethrum and survival rate of living arthopods obtained by canopy fogging in Central Amazonia. In: Stork, N.E.; Adis, J.; Didham, R.K. (eds.) Canopy arthropods. Chapman ; Hall, London: 67-81.

Adis, J; Harada, A.Y.; Rafael, J.A.; Vidal, S. 1998. Kontrollieren Ameisen die Dipterenfauna neotropischer Baumkronen? Verhandlungen Westdeutscher Entomologentag Düsseldorf 1997 (Löbbecke-Museum Düsseldorf): in press. 
Erwin, T,L. 1983. Tropical forest canopies: the last biotic frontier. Bull. Ent. Soc. America, 29(1): 14-19.

Erwin, T.L. 1989. Canopy arthropod biodiversity: a chronology of sampling techniques and results. Revista Peruana de Entomologia, 32: 71-77

Floren, A; Linsenmair, K.E. 1997a. Diversity and recolonization dynamics of selected arthropod groups on different tree species in a lowland rainforest in Sabah, Malaysia with special reference to Formicidae. In: Stork, N.E.; Adis, J.; Didham, R.K. (eds). Canopy arthropods. Chapman Hall, London: 333-381.

Floren, A; Linsenmair, K.E. 1997b. Diversity and recolonisation dynamics of arthropod communities in a lowland rain forest in Sabah, Malaysia, In: Ulrich, H. (ed) Tropical biodiversity and systematics. Proceedings of the International Symposium on Biodiversity and Systematics in Tropical Ecosystems., Bonn, 1994. Zoologisches Forschungsinstitut und Museum Alexander Koenig, Bonn: 245-249.

Harada, A.Y.; Adis, J. 1997. The ant fauna of tree canopies in Central Amazonia: a first assessment. In: Stork, N.E; Adis, J.; Didham, R.K. (eds). Canopy arthropods. Chapman ; Hall, London: 382-400.

Hero, J.M. 1990. An illustrated key to tadpoles occurring in the Central Amazonian rainforest, Manaus, Amazonas, Brazil. Amazoniana, 11(2): 201-262.

Höfer, H.; Brescovit, A.D.; Adis, J.; Paarmann, W. 1994. The spider fauna of Neotropical tree canopies in Central Amazonia: first results. Studies on Neotropical Fauna and Environment, 29(I): 23-32.

Linsenmair, K.E. 1990. Tropische Biodiversität: Befunde und offene Probleme. Verhandlungen der Deutschen Zoologischen Gesellschaft, 83: 245-261.

Loureiro,A.A.; Silva, M.F. da 1968. Catálogo das madeiras da Amazónia. Vol.1, SUDAM, Belém. 433 p.
Memmott, J.; Godfray, H.C.J.; Bolton, B. 1993. Predation and parasitism in a tropical herbivore community. Ecological Entomology: 18: 348-352.

Penny, N.D.; Arias, J.R. 1982. Insects of an Amazon forest. Columbia University Press, New York. 269 p.

Prance, G.T. 1990. The floristic composition of the forests of central Amazonian Brazil. In: Gentry, A.H. (ed). Four Neotropical Rainforests, Yale University Press, New Haven: 159-174.

Ribeiro, M. de N.G.; Adis, J. 1984. Local rainfall variability - a potential bias for bioecological studies in the Central Amazon. Acta Amazonica, 14(1/2): 159-174.

Seifert, B. 1993. Die freilebenden Ameisen Deutschlands (Hymenoptera: Formicidae) und Angaben zu deren Taxonomie und Verbreitung. Abhandlungen und Berichte des Naturkundemuseums Görlitz, 67(3): 1-44.

Stork, N.E. 1988. Insect diversity: facts, fictions and speculations. Biological Journal of the Linnean Society, 35: 321-337.

Stork, N.E. 1991. The composition of the arthropod fauna of Bornean lowland rain forest trees. Journal of Tropical Ecology, 7: $161-180$.

Stork, N.E.; Brendell, M.J.D. 1990. Variation in the insect fauna of Sulawesi trees with season, altitude and forest type. In: Knight, W.J.; Holloway, J.D. (eds). Insects and the rain forest of South East Asia (Wallacea). Royal Entomological Society of London, London:173-190.

Strümpel, H. 1985. Mutualistische Beziehungen zwischen neotropischen Buckelzirpen (Homoptera: Membracidae) und Ameisen. Verhandiungen der Deutschen Zoologischen Gesellschaft. 78: 342 .

Willis, E.O. 1977. Lista prelininar das aves da parte noroeste e áreas vizinhas da Reserva Ducke, Amazonas, Brasil, Revista Brasileira de Biologia, 37(3): 585-601. 